\title{
Research on Construction of Major Drainage System for urban area of Shijiazhuang*
}

\author{
Chunyang Zhang, Jiazhuo Wang, Yingjun Hu, Wei Zhang \\ China Academy of Urban Planning \& Design, Beijing 100037, China
}

Received 15 September 2015

Accepted 22 October 2015

\begin{abstract}
In recent years, many cities of China suffered from urban waterlogging, therefore, prevention of urban waterlogging became one of the main targets of urban drainage. Based on the comprehensive plan of drainage and waterlogging Prevention of Shijiazhuang, this study introduced the relationship between major and minor drainage systems, as well as the significance of major drainage system construction. According to the current problems of urban drainage systems of Shijiazhuang, two-dimensional surface flow modelling tools was applied, with the consideration of urban master planning, major drainage system was established. Which contains eight conveyances for exceedance flow based on urban rivers and fifteen major detention \& retention facilities based on urban green space. Thereby, effective alleviation of urban waterlogging was achieved.
\end{abstract}

Keywords: waterlogging prevention, major drainage system, minor drainage system, conveyance for exceedance flow, detention and retention facilities

\section{石家庄市中心城区大排水系统构建研究}

张春洋, 王家卓, 胡应均, 张伟

(中国城市规划设计研究院，北京 100037)

摘要: 近年来, 我国城市内涝频发, 如何科学、有效地解决城市内涝成为城市排水工作的重点。本研 究以石家庄市排水 (雨水) 防涝综合规划为例, 介绍了城市排水防涝体系中大小排水系统的内涵, 分析了 构建大排水系统的重要意义。结合石家庄市实际情况, 分析石家庄市大排水系统存在的主要问题, 并以问 题导向和需求导向为主线，使用地表二维水力模型等工具，采用 “以排为主，蓄排结合”的策略，结合城 市用地布局及公园绿地规划, 统筹构建大排水系统, 包括以水系为载体的涝水行泄通道以及以公园绿地为 载体的大型调蓄设施。其中, 规划新增或恢复涝水行泄通道 8 条, 大型调蓄设施 15 处, 有效解决城市排水 出路问题，缓解石家庄市城市内涝。

关键词: 排水防涝; 大排水系统; 小排水系统; 行泄通道; 调蓄设施

\footnotetext{
“基金资助：基金资助：国家科技支撑计划（2012BAJ01B01）、国家科技支撑计划（2012BAJ15B01）
} 作者简介: 张春洋 (1985 年), 男, 河南驻马店人, 硕士, 工程师。E-mail: 1163239996@qq.com 


\section{1. 引言}

2010 年, 住房城乡建设部对全国 351 个城市内 涝情况进行了系统调研, 结果显示, 2008 2010 年 共有 289 个城市发生了不同程度的内涝, 占调查城 市数的 $80 \%$ 。我国城市内涝问题具有发生范围广、 积水深度大、积水时间长等三个明显特征。全国一 些主要城市如武汉、北京、广州、深圳、福州、南 京、南昌等地先后发生了较为严重的城市内涝, 影 响了城市正常运行, 对城市正常运行和人民生命财 产安全造成了不利影响 ${ }^{[1]}$ 。

为此, 2013 年国务院发布《关于做好城市排 水防涝设施建设工作的通知》(国办发 $[23]$ 号), 要 求加强城市排水防涝设施建设, 用 10 年左右的时间, 建成较为完善的城市排水防涝工程体系。

我国在以往的城市规划和建设中, 一般只强调 对小重现期降雨有效的小排水系统, 缺乏应对高重 现期的大排水系统。长期以来, 在城市开发建设过 程中, 城市河湖水系等超标雨水的行泄通道没有得 到充分的保护, 集中表现在: 一是部分河湖水系被 侵占或填埋, 部分明河变成暗暗沟, 破坏了原有的 水文特征, 影响了城市排水防涝安全; 二是部分承 担排涝功能的城市内河被改造为景观水体, 裁弯取 直将自然河道改造为人工水面, 减少坡度, 设置拦 水坝、雨水口闸门等构筑物, 降低了河道的排涝能 力; 三是城市水系蓝线管理制度不健全, 管理不严, 无法有效保护水系生态空间。

近年来, 大排水系统的在城市内涝防治中的作 用逐渐被重视。2013 年 6 月, 住房和城乡建设部发 布《城市排水 (雨水) 防涝综合规划编制大纲》, 将 涝水行泄通道和调蓄设施作为防涝体系的重要组成 部分。《室外排水设计规范》(GB50014-2006)（2014 版) 提出, 要充分利用河道、湖泊、湿地、沟塘等 城市自然蓄排水设施, 作为城市内涝防治、排水的 重要载体。
在北方平原城市, 地势平坦, 水系分布少, 排 水管网坡度小, 排水分区大, 单个排水管道较长。 仅依靠小排水系统难以有效解决城市内涝问题, 必 须构建以涝水行泄通道与调蓄空间组成的大排水系 统 ${ }^{[2]}$ 。

本文以石家庄市城市排水（雨水）防涝综合规 划为例, 介绍平原城市排水防涝体系中大排水系统 的构建的规划思路和规划方案，对我国同类型城市 具有一定的参考作用。

\section{2. 大排水系统和小排水系统的关系}

在西方国家，按照应对暴雨重现期的不同进行 划分, 城市排水系统通常分为大小两套排水系统 ${ }^{[3-5]}$ 。

小排水系统 (minor system), 是指城市雨水管 渠、雨水提升泵站等城市排水系统，用以排除低重 现期（一般为 5 年以内）的暴雨产生的径流。

大排水系统（major system）则用以应对超过小 排水系统应对能力的高重现期的罕见暴雨, 以地表 排水通道、地表沟渠、城市河湖水系、排水深遂、 大型调蓄空间等为主要构成 ${ }^{[6]}$ 。

大排水系统和小排水系统的关系如图 1 所示。 大排水系统与小排水系统相辅相成, 组合构成了一 个有机整体并相互衔接、共同作用，综合作用应对 较高的排水防涝标准，西方发达国家一般按 100 年 一遇的暴雨进行校核 ${ }^{[7]}$ 。

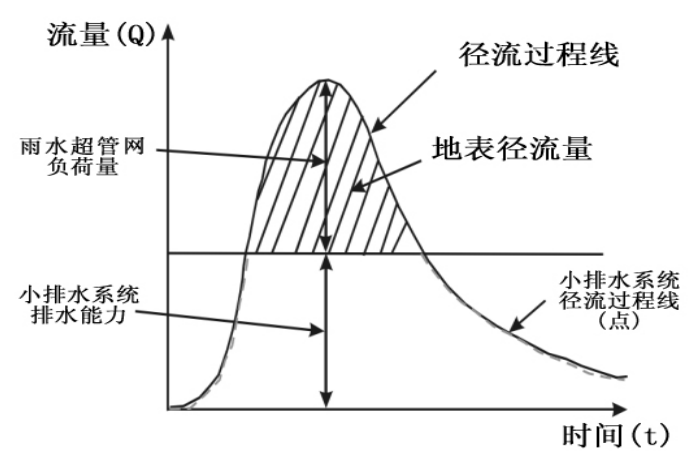

图 1 大排水系统与小排水系统关系示意图 


\section{3. 石家庄市中心城区排水系统现状}

\section{1 城市概况}

石家庄为河北省省会, 京津冀地区重要中心城 市。市区西依太行山, 北濒滹沱河, 东南部为辽阔 的河北平原。城区地势较为平坦, 自然地形由西北 向东南倾斜, 平均坡度约为千分之一。石家庄属暖 温带大陆性半湿润季风型气候。年平均气温 $13.3^{\circ} \mathrm{C}$, 年平均降水量为 $534.6 \mathrm{~mm}$ 。

根据石家庄市城市总体规划（2011-2020 年), 2020 年中心城区城市人口将达到 300 万人, 城市建 设用地规模控制在 $287 \mathrm{~km}^{2}$ 以内 ${ }^{[8]}$ 。石家庄市中心城 区用地规划如图 2 所示。

\section{2 现状排港体系情况}

石家庄现状市政雨水管道 $433.5 \mathrm{~km}$, 合流管道 $128.3 \mathrm{~km}$, 雨水洜站 32 座。

城市主城区现有明渠 10 条, 其中石津北干渠、
石津南支渠、四支渠、五支渠、桥西明渠、元村明 渠、南栗明渠、东明渠、总退水渠和引水中线, 其 中石津南支渠、五支渠、桥西明渠（长丰路一南新 街)、元村明渠、东明渠、总退水渠（南三环以北） 和引水中线 7 条明渠承担汛期排涝的功能外, 平时 主要为景观水体; 南栗明渠和桥西明渠（南新街一 南二环）为排水明渠; 石津北干渠为灌溉明渠，南 水北调中线工程计划将其作为输水明渠（图 3 )。

\section{3 石家庄市大排水系统存在的问题分析}

\section{(1)城市排水防漟体系建设滞后于城市开发}

1954 年至 80 年代期间, 伴随着城市拓展, 石 家庄兴建了总退水渠、元村明渠、南栗明渠、桥西 明渠、东明渠、五支渠等一系列城市排水明渠，对 城市排水防涝起到重要作用。然而进入新世纪以来, 城市快速东扩, 除新建的东南环水系外（定位为景 观水体, 基本失去排水功能), 基本再无新建城市涝 水行泄通道。

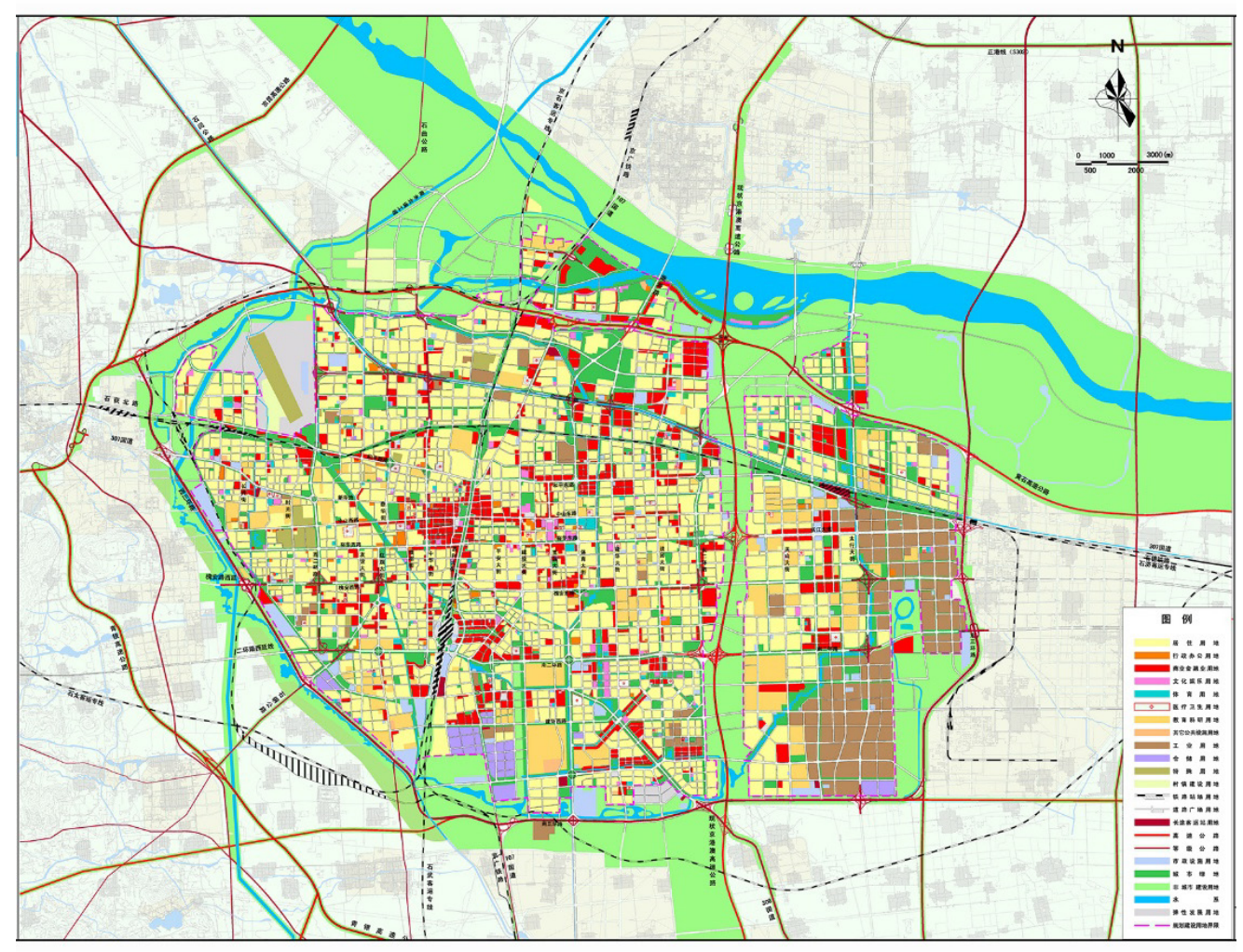

图 2 石家庄市中心城区用地规划图 
(2)原有的城市排水明渠被改造为景观水体, 排水能 力降低

在城市发展过程中，中心城区排水明渠的功能 定位逐渐由排水通道变为城市景观水体, 设置大量 水坝、闸门等水工构筑物控制水位, 导致暴雨期间, 河道排水能力下降, 进而对汇入的市政管道产生顶 托, 造成内涝。

\section{(3)城市新区排水出路不畅, 局部地段内涝严重}

石家庄市排水出路问题集中在城市东部产业区
和城市南部地区。对于东部产业区, 现状主要排水 通道主要依靠环山湖以及汪洋沟。随着开发区建成 区面积不断扩大，环山湖的容量满足不了雨水排放 要求, 造成大面积内涝。汪洋沟城区段现状排水能 力较小，随着良村开发区的快速建设，排水出路问 题也日益凸现。对于城市南部地区, 现状排水通道 主要依靠总退水渠（图 4), 承担了约 $138 \mathrm{~km} 2$ 建成 区的排水，但最大设计流量仅为 $175 \mathrm{~m} 3 / \mathrm{s}$, 排水能 力不足谋不。

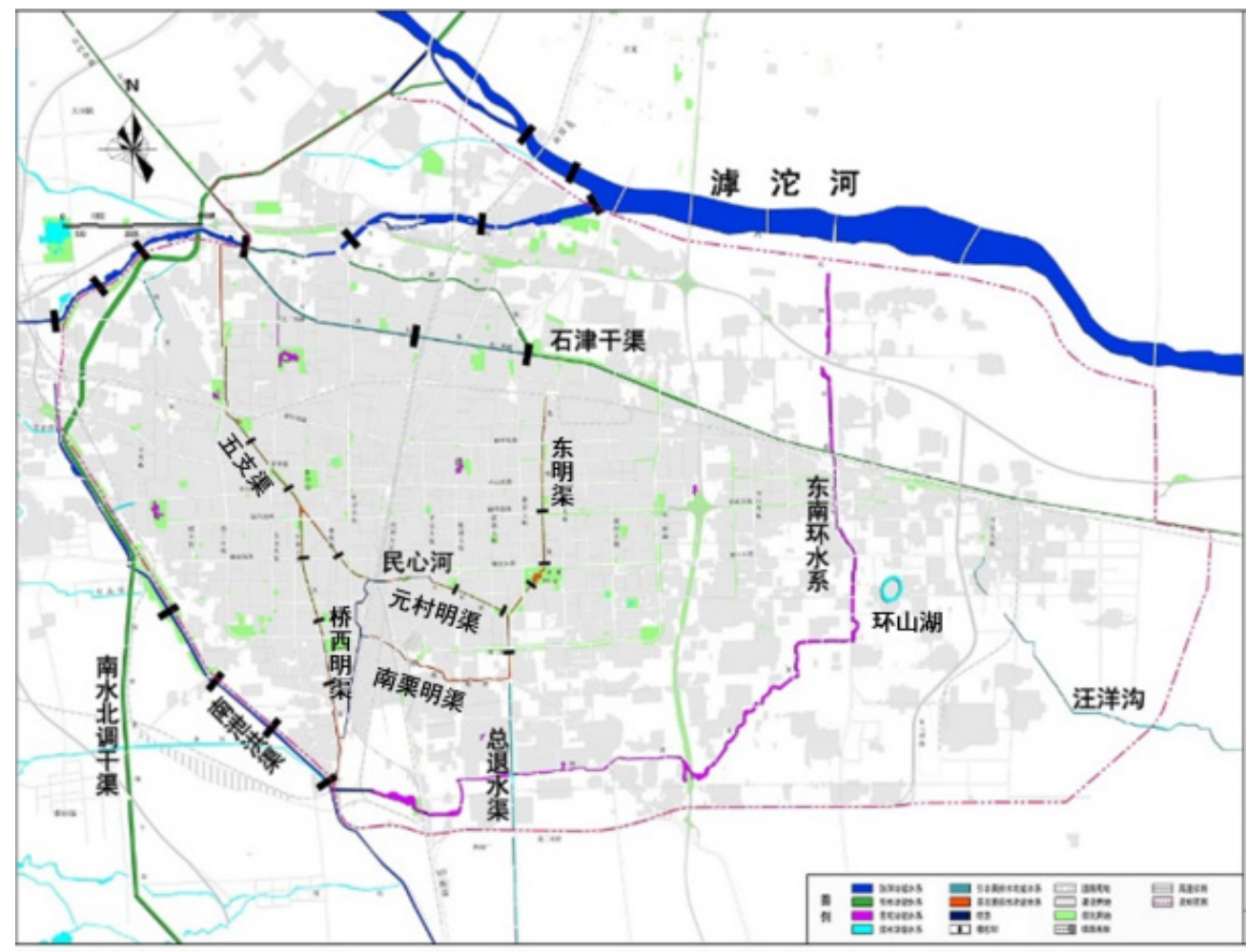

图 3 石家庄市现状水系分布图 


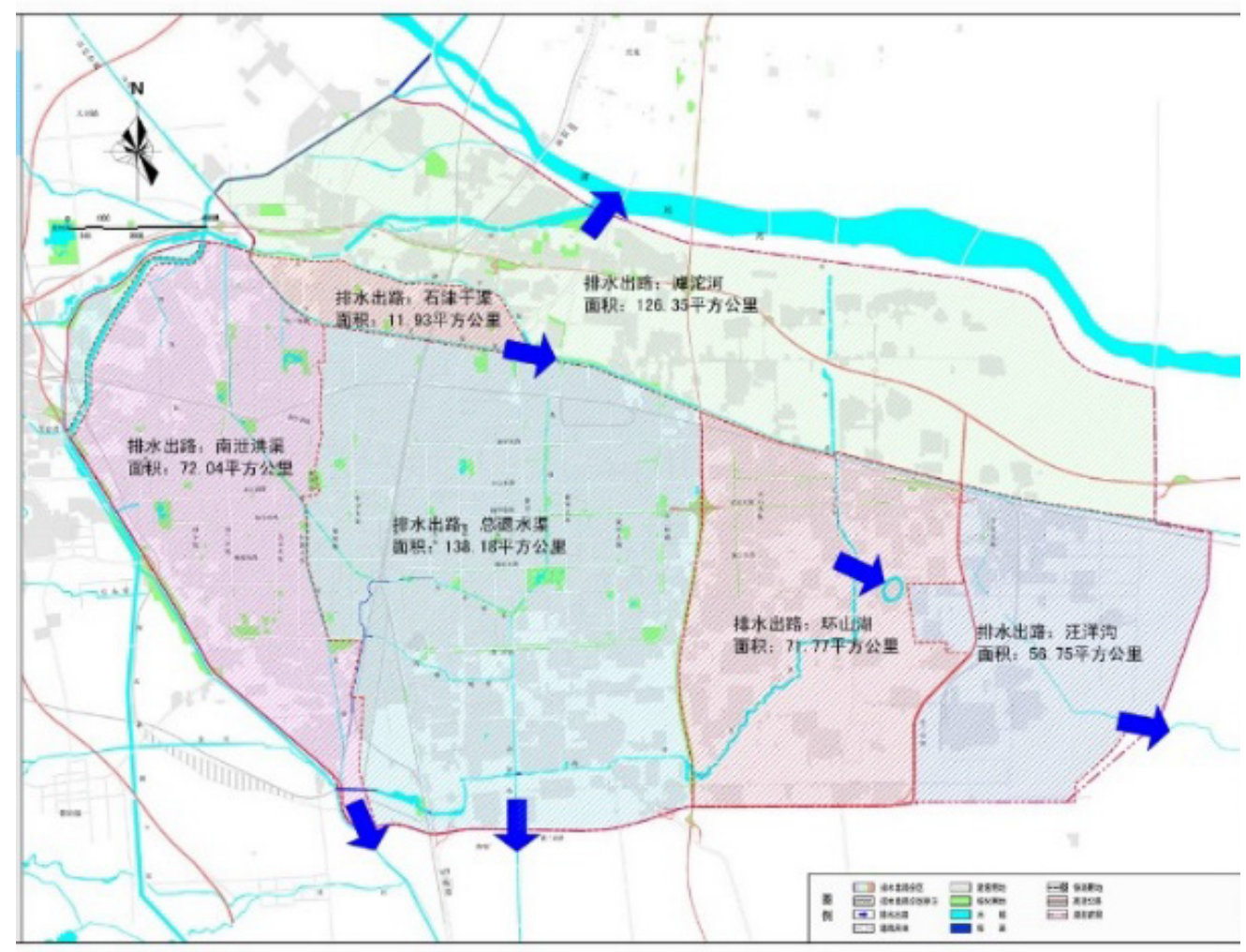

图 4 现状排水出路示意图

\section{4. 石家庄市大排水系统构建}

\section{1 构建思路和原则}

坚持问题导向和需求导向相结合, 以排为主, 蓄排结合, 重点解决排水出路缺乏、雨水分区面积 过大等问题。

按照因地制宜、流域统筹的原则, 综合考虑城 市用地布局和自然地貌, 采取 “西部整治、中南部 联通、东部地区新增” 的策略, 构建涝水行泄通道; 根据石家庄市河湖水系和公园绿地的规划布局, 建 设调蓄空间, 统筹构建大排水系统, 保障提高城市 暴雨内涝风险的应对能力。

\section{2 构建方法}

\section{(1) 自然汇水流场分析}

根据石家庄的现状地形地貌, 使用 MIKE 21 地 表径流模型, 输入石家庄典型降雨数据。在不考虑 管网排水和土壤下渗的条件下, 分析暴雨时地表径 流的汇聚方向和趋势, 辅助大排水系统构建。由图 5 可以看出, 暴雨时, 石家庄中心城区除石津干渠
以北地区地表径流向北汇入滹沱河以外, 其他地区 均向东南方向汇流, 即城市大部分面积排水的主要 出路为东南方向。

\section{(2)优化城市排水出路, 科学构建大排水系统}

对城市排水分区进行优化调整，使用 MIKE 11、 MIKE 21 以及 MIKE Urban 耦合城市地表 dem、排 水管网以及城市水系。借助模型综合分析每个片区 内城市暴雨径流产生量, 优化城市排水出路, 合理 确定大排水系统的布局和规模（图 6)。

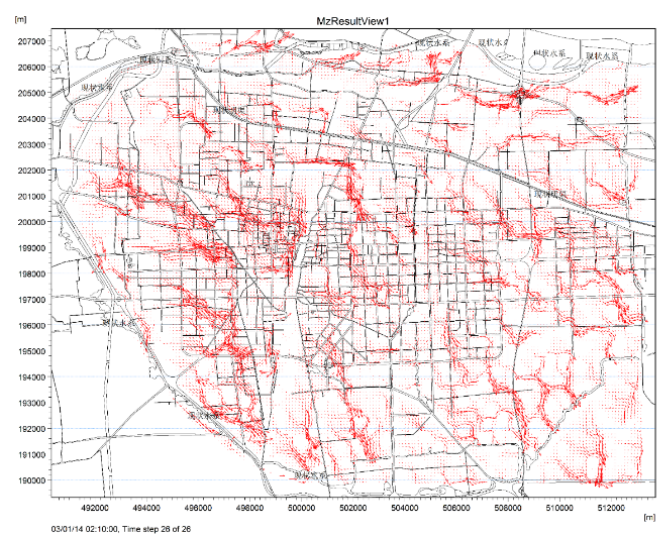

图 5 自然汇水流场分析 


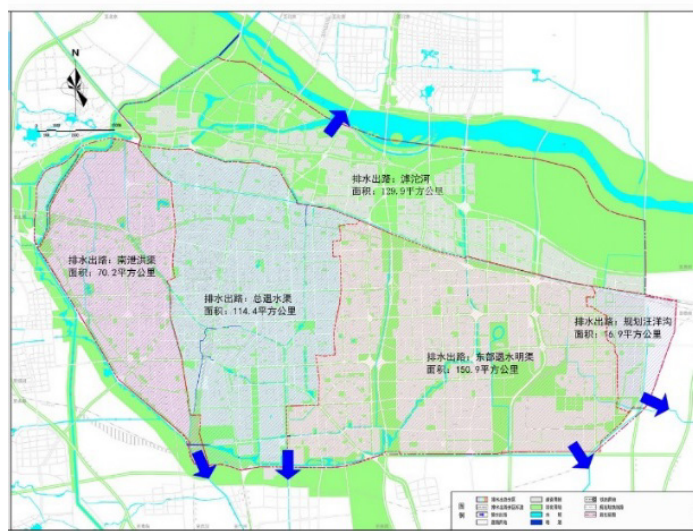

图 6 规划排水出路示意图

\section{3 石家庄市大排水系统构建}

\subsection{1 涝水行泄通道}

规划保留中心城区现状水系, 对能力不足的, 进行改造提升。此外, 对四支渠进行恢复, 在城市
东部新区增涝水行泄通道, 如图 7 和表 1 所示。

\section{(1) 现状水系管理提升}

五支渠、桥西明渠、元村明渠、东明渠等现状 内环水系兼具城市景观与排水功能, 两岸均已高密 度开发, 河道缺少扩展空间。规划保留现状渠道断 面，主要通过定期清淤疏浚，包括检修沿线闸门、 加强橡胶坝等水工设施调度, 确保渠道过流能力。 建立汛期联合调度机制, 建立预警机制, 及时调整 水位, 提高排水能力。

\section{(2) 四支渠}

规划恢复四支渠，以减轻五支渠系统的排水压 力。四支渠路由结合规划路网进行布置, 最终汇入 南泄洪渠, 总长 $10.4 \mathrm{~km}$ 。汇水范围为南水北调中线 干渠与四支渠之间地区以及四支渠以东部分地区， 总面积约为 $16.3 \mathrm{~km}^{2}$ (图 8)。

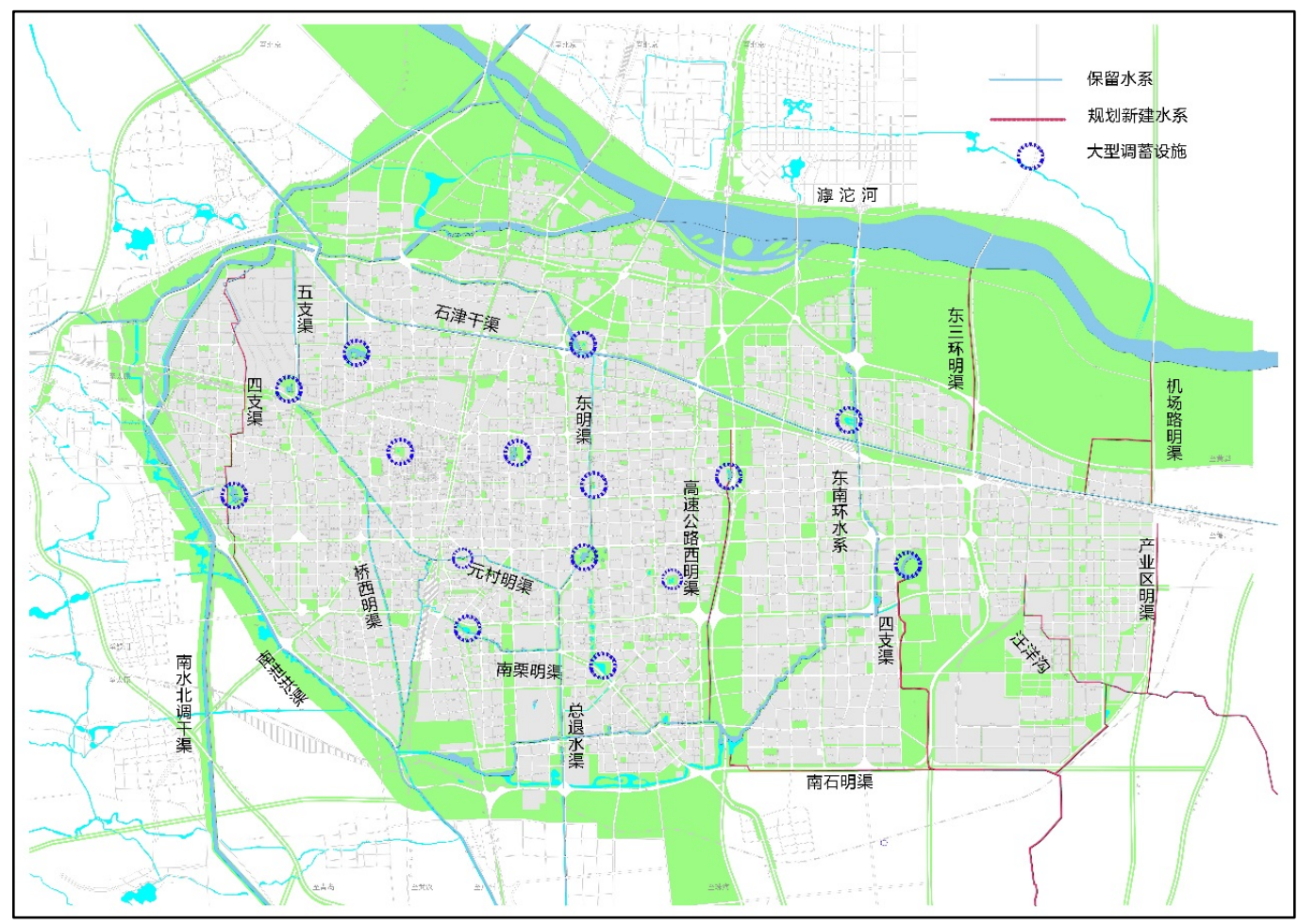

图 7 石家庄市大排水系统构建示意图 
表 1 规划涝水行泄通道一览表

\begin{tabular}{ccccc}
\hline 名称 & 断面宽度 $(\mathbf{m})$ & 总长 $(\mathbf{k m})$ & 坡度 $(\% \mathbf{o})$ & 出口设计流量 $\left(\mathbf{m}^{\mathbf{3}} / \mathbf{s}\right)$ \\
\hline 四支渠 & $12-15$ & 10.4 & $0.4-0.8$ & 64 \\
高速公路西明渠 & $14-20$ & 9.2 & $0.3-0.9$ & 108 \\
南石明渠 & 16 & 6.7 & $0.3-0.5$ & 47 \\
东部退水明渠 & $20-35$ & 16.5 & $0.4-0.8$ & 138 \\
产业区东明渠 & 16 & 5.7 & $0.3-0.5$ & 100 \\
汪洋沟 & 18 & 5.2 & $0.2-0.4$ & 17 \\
东三环明渠 & $10-12$ & 5.6 & $0.5-1.0$ & 42 \\
机场路明渠 & $12-16$ & 7.8 & $0.1-0.5$ & 27 \\
\hline
\end{tabular}

\section{(3) 东部退水明渠}

东南环水系以东与东石环路之间大部分地区属 于相对独立的排水系统, 总面积约为 $38.3 \mathrm{~km}^{2}$ 。现 状北部地区排入环山湖进行调蓄, 其余地区雨水无 明确排放出路。规划新建东部退水明渠, 连接东南 环水系以及环山湖, 下游接入洨河（图 9)。

\section{(4) 南石明渠}

东南环水系设计之初定位为景观水体和通航航 道, 渠底几乎没有坡度, 排水能力较弱。规划新建 南石明渠, 连接东南环水系, 向东汇入规划东部退 水明渠, 增加东南环水系向下游的排水流量, 进而 增强其蓄排能力（图 10）。

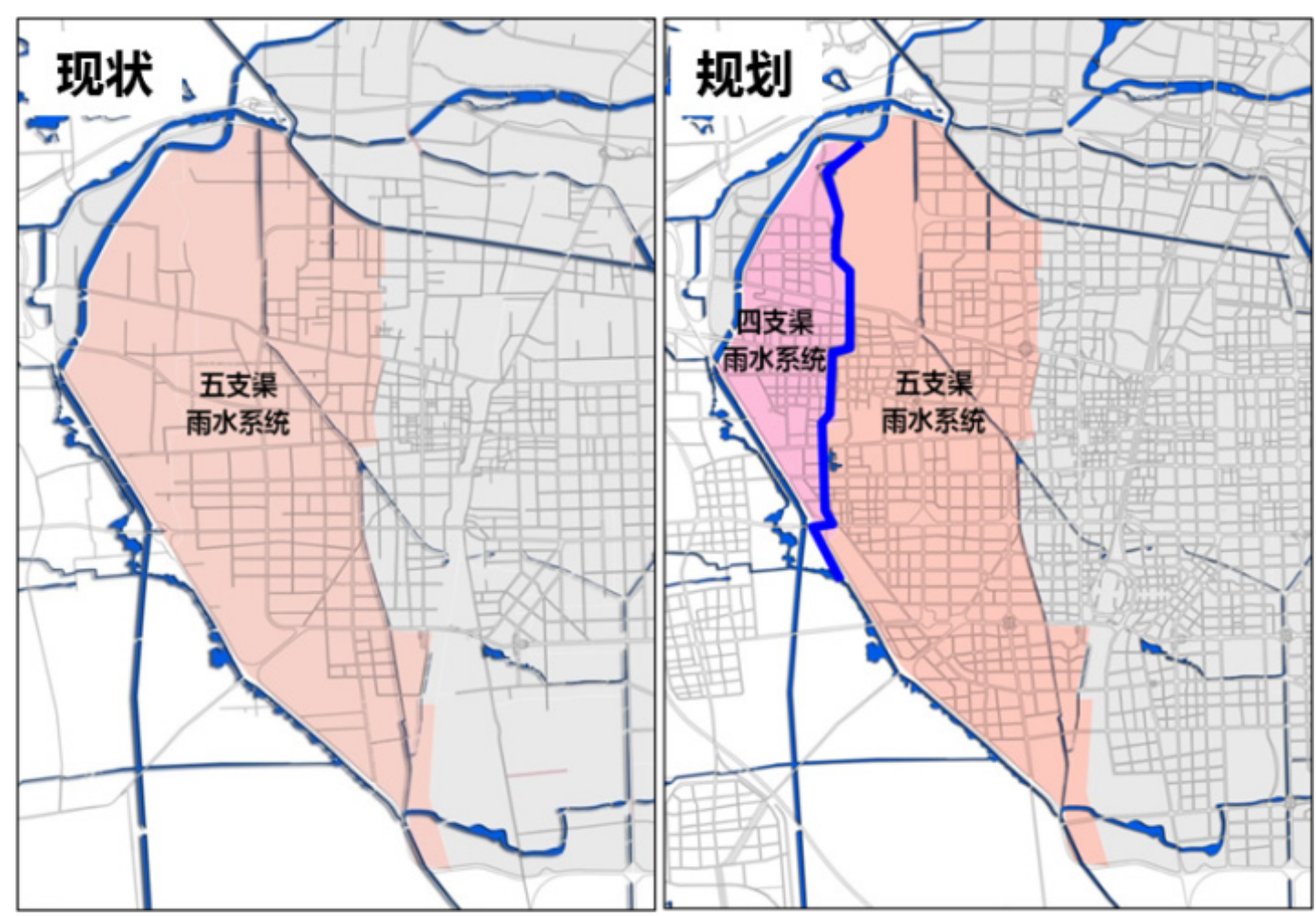

图 8 四支渠与五支渠雨水分区调整示意图 


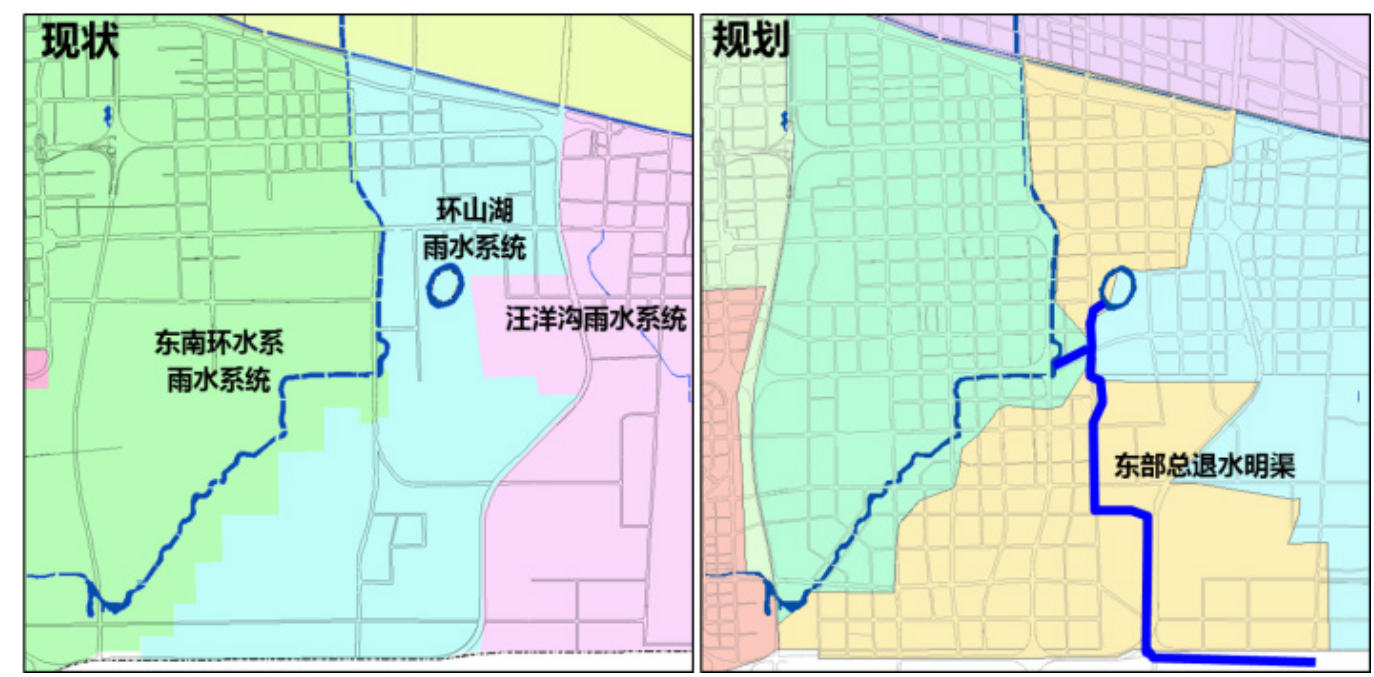

图 9 规划东部退水明渠路径图

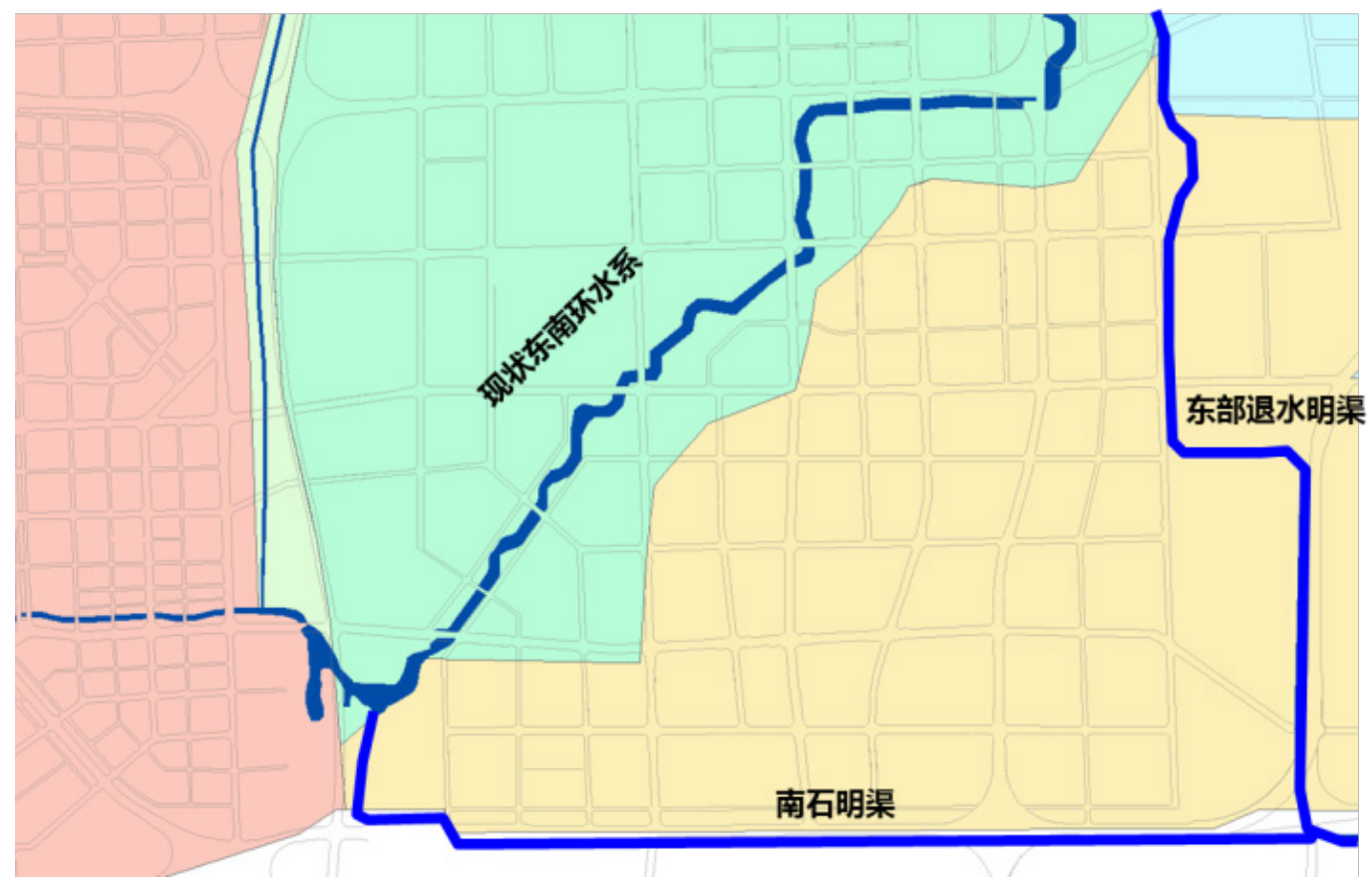

图 10 规划南石明渠路径图

\section{(5) 高速公路西明渠}

石津干渠以南、东二环以北、东明渠以东、京 珠高速公路以西大部分地区现状排水主通道为东二 环路雨水主干管, 现状排水压力较大, 内涝频发。 规划结合京港澳高速公路西侧大面积绿地, 新建高 速公路西明渠, 主要承担石津干渠以南、东岗路以 北、谈固大街以东、京珠高速公路以西片区的雨水
排放, 汇水面积约为 $15.8 \mathrm{~km}^{2}$, 用于缓解东明渠的 排水压力。新建明渠向南接入东南环水系, 总长约 $9.2 \mathrm{~km}$ 。(图 11)。

\section{(6) 澞沱河雨水分区排水明渠}

规划在石津干渠以北, 玉山大街西侧新建一条 明渠 (东三环明渠), 收集两侧地块雨水, 并在出口 处设置洜站排入滹沱河, 汇水面积约为 $8.4 \mathrm{~km}^{2}$ 。 


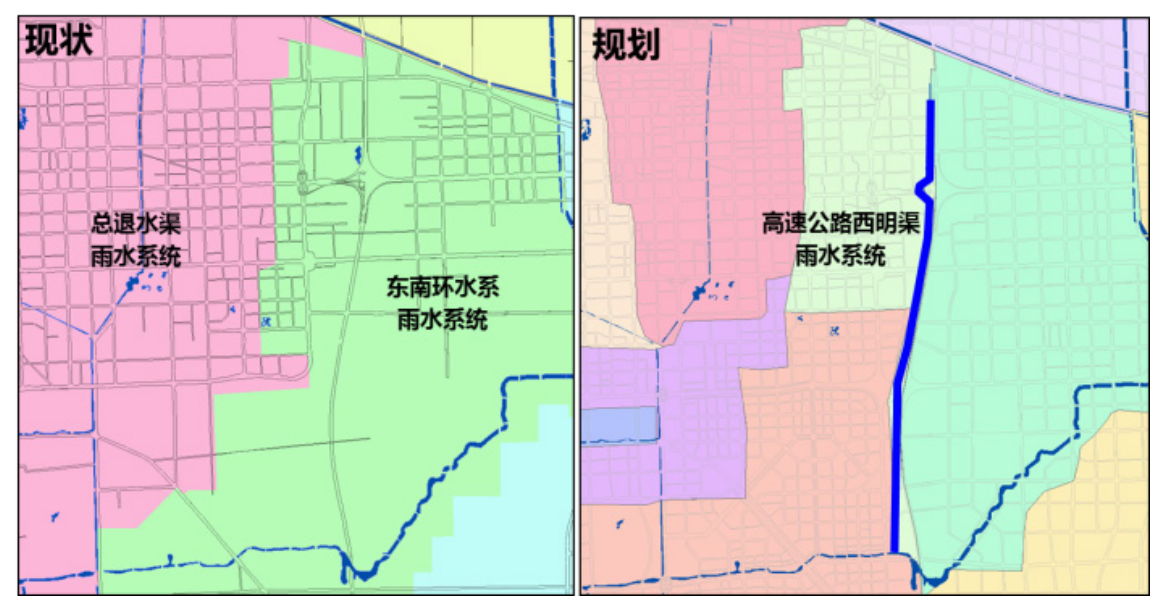

图 11 规划高速公路西明渠示意图
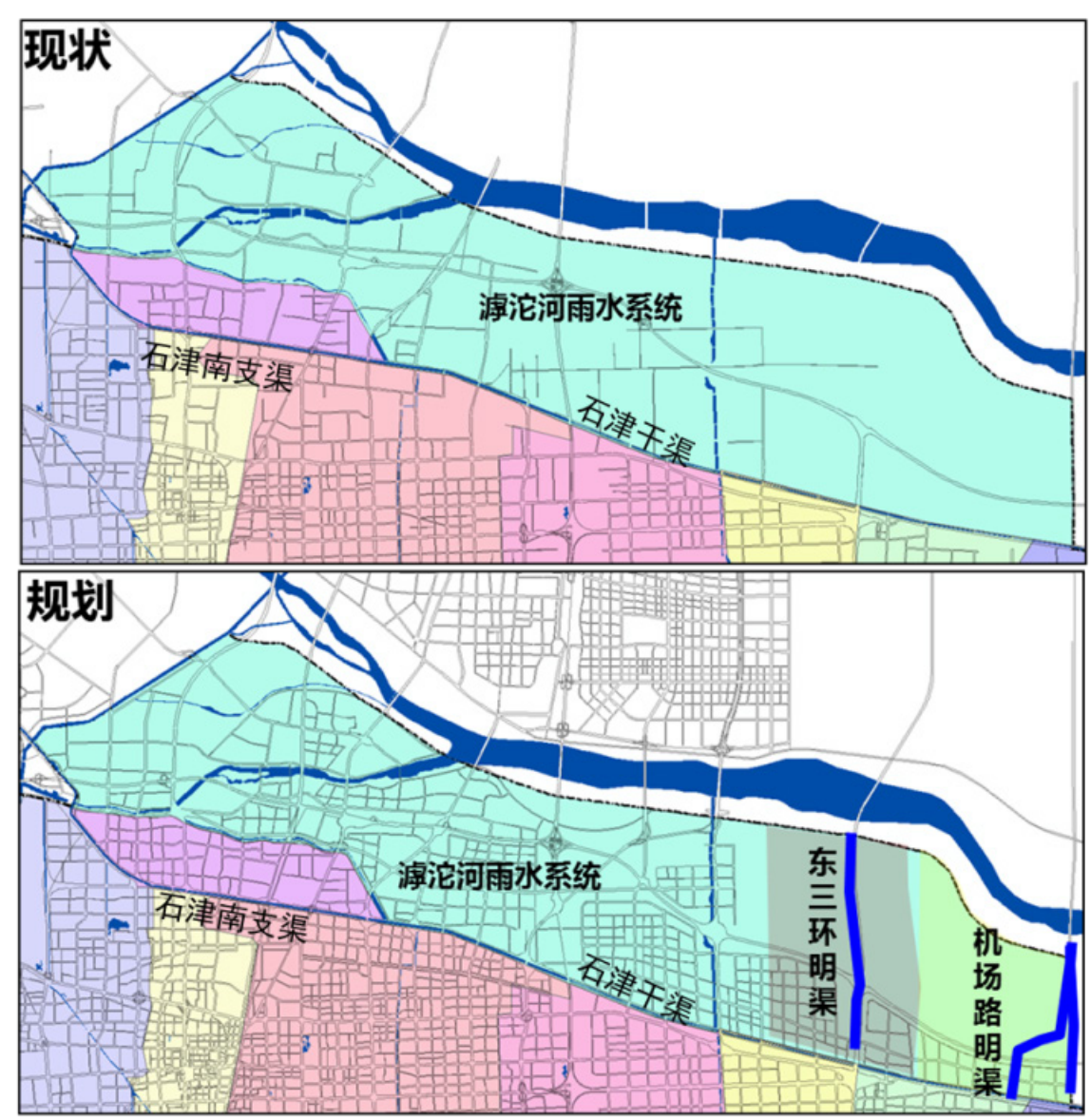

图 12. 规划机场路明渠和东三环明渠示意图

在石津干渠以北, 机场路西侧规划两条明渠 (机 场路明渠), 将工业中街与机场路之间地区雨水通过 原站排入滹沱河, 汇水面积约为 $4.4 \mathrm{~km}^{2}$ (图 12)。

\section{(7) 产业区东明渠}

良村开发区东部地区现状排水主要依靠市政管 网, 最终汇入汪洋沟。由于汇水面积较大, 主干管 


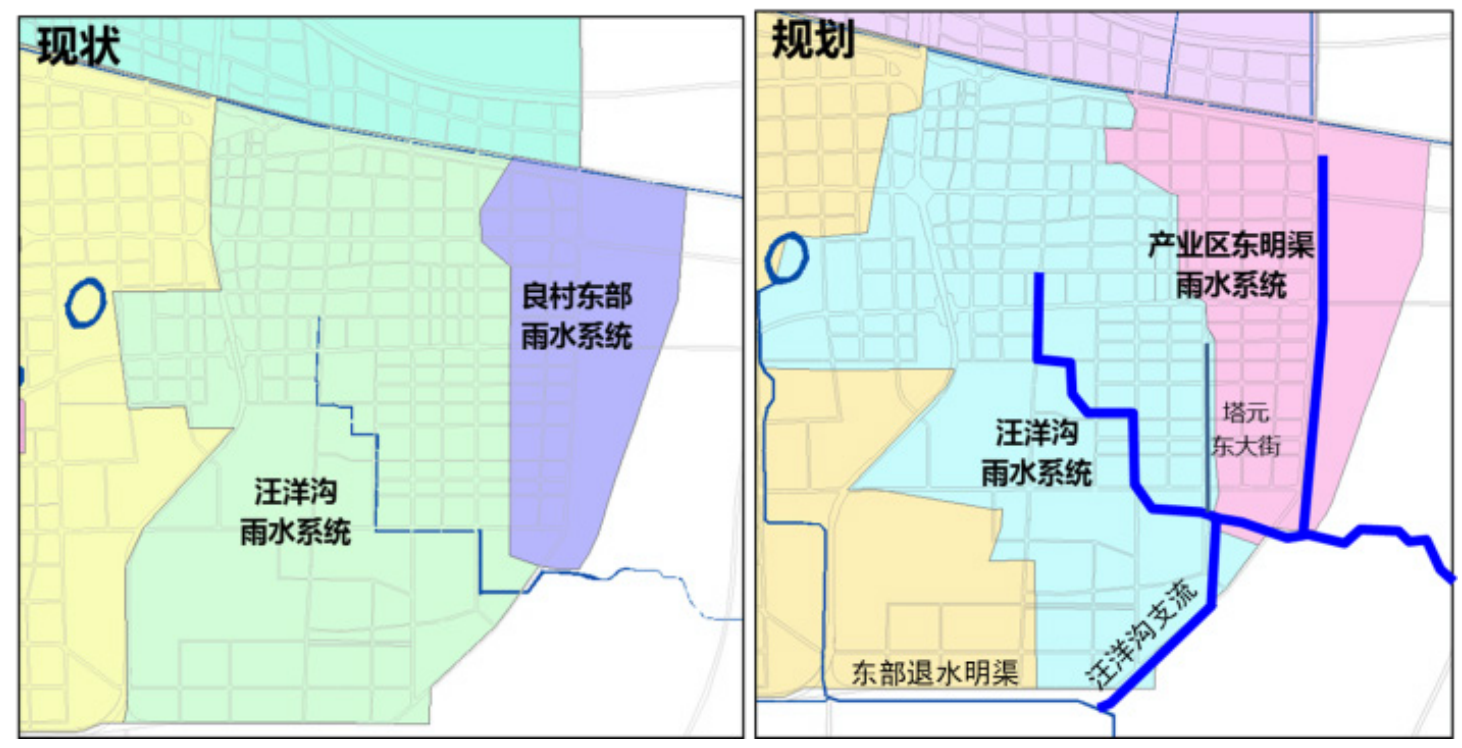

图 13 规划产业区明渠和汪洋沟示意图

尺寸偏小, 排水能力有限。规划新建产业区东明渠, 由北向南接入汪洋沟。承担石津干渠以南、汪洋沟 以北、塔元东大街以东等地区的雨水排放, 减轻现 状排水主干管压力, 提高汪洋沟、产业东明渠雨水 分区内的排水能力（图 13)。

\section{(8) 汪洋沟}

汪洋沟区域共用河流, 下游排入邢台市, 为了 不对下游城市造成洪涝影响, 上级水利部门确定石 家庄良村开发区雨水的排入总量不超过 $17 \mathrm{~m}^{3} / \mathrm{s}$, 与 良村片区的排水要求产生矛盾。

规划新建汪洋沟支流，分流良村开发区雨水流 量, 减轻现状汪洋沟排水压力。规划汪洋沟支流沿 机场路向西南接入东部退水明渠, 最终汇入洨河。 规划汪洋沟支流断面为复式, 宽度 $15 \sim 28 \mathrm{~m}$, 总长约

\section{$9.4 \mathrm{~km}$ 。}

\subsection{2 调蓄设施}

地面雨水调蓄设施主要结合石家庄市内涝风险 评估结果以及城市水系、绿地公园的布局, 将公园 中现有的水体作为超标准降雨的调蓄空间。通过坚 向设计, 将周围地块雨水径流通过雨水管网或道路 边沟, 引入公园绿地和水系。
一方面，公园可以通过调蓄一定容量的雨水， 减小峰值流量; 另一方面通过滞留一定容量的雨水 实现雨水资源综合利用。规划设置大型调蓄空间 15 处，总调蓄规模达到 40 万 $\mathrm{m}^{3}$ （图 7)。

\section{5. 结论与讨论}

石家庄市为我国平原城市的代表，地势平坦， 自然水系不发达。在以土地开发为主导的城市建设 进程中，没有及时保护和新建承担城市排水功能的 河渠，导致城市建成以后，缺少排水出路，造成内 港。

本文结合石家庄市实际情况, 结合城市用地布 局及公园绿地规划，统筹构建大排水系统，包括以 城市水系为载体的涝水行泄通道以及以公园绿地为 载体的大型调蓄设施。

石家庄市大排水系统的构建，对于我国平原城 市具有一定的借鉴意义。解决城市内涝问题, 需要 大小排水系统有机衔接, 在提高市政排水管道标准 的同时，构建 “以排为主，蓄排结合” 的大排水系 统, 解决城市排水出路问题。

在构建城市大排水系统时，应综合考虑城市发 
展趋势和城市绿地、水系规划布局, 统筹协调, 结 合城市地形和坚向关系, 合理选择大排水系统的形 式及构成，并预留大排水系统空间。

构建城市大排水系统，宜采用现代化科学技术， 使用国内外先进的水力模型工具, 耦合城市地形、 排水管网以及河流水系, 综合评估排水系统能力, 辅助大排水系统的规划设计, 包括建设标准、规模 以及断面形式等, 不断提高规划设计水平。

\section{参考文献}

[1] 谢映霞. 从城市内涝灾害频发看排水规划的发 展趋势 [J]. 城市规划,2013,37(2):45-50.

[2] 徐连军, 张善发, 朱砂砾, 高原, 李兵. 城市陆 域排水防涝体系构建方法与技术关键探讨 [J]. 中国给水排水，2013,19（19): 141-145.

[3] David Butler, John W. Davies. Urban Drainage(2nd Edition)[M], London\& New York: CRC Press,2004.

[4] U.S. Department of Transportation. Urban Drainage Design Manual (Third Edition) [M]. Washington: Hydraulics Engineering Publication, 2009.

[5] Queensland Government. Queensland Urban Drainage Manual[M]. Queensland: Queensland Government, 2007.

[6] 周玉文. 构建三套工程体系确保城市洪涝安全 $[\mathrm{J}]$. 给水排水, 2011, 37(4):12-13.

[7] 车伍, 杨正, 赵杨, 李俊奇. 中国城市内涝防治 与大小排水系统分析 [J]. 2013, 29(16):13-19.

[8] 石家庄市人民政府，石家庄市城市总体规划 (2011-2020)[R]. 2011 年. 